\title{
Nekton use of Ruppia maritima and non-vegetated bottom habitat types within brackish marsh ponds
}

\author{
Sarai Kanouse ${ }^{1}$, Megan K. La Peyre ${ }^{2, *}$, J. Andrew Nyman ${ }^{1}$ \\ ${ }^{1}$ School of Renewable Natural Resources, Louisiana State University Agricultural Center, Baton Rouge, Louisiana 70803, USA \\ ${ }^{2}$ US Geological Survey, Louisiana Fish and Wildlife Cooperative Research Unit, School of Renewable Natural Resources, \\ Louisiana State University Agricultural Center, Baton Rouge, Louisiana 70803, USA
}

\begin{abstract}
Nekton (fishes and decapod crustaceans) use of brackish submerged aquatic vegetation (SAV) habitat has been largely overlooked in comparison to fresh and marine SAV habitats. This study was designed to examine nekton use of brackish marsh SAV habitat and non-vegetated bottom. Specifically, we examined the effects of habitat location (defined by SAV distance from marsh edge) and complexity (defined by SAV biomass) on nekton community density, biomass, and diversity in shallow water brackish marsh ponds, which contained monospecific beds of Ruppia maritima L. Three habitat types were investigated: (1) inner-pond SAV (SAV habitat $>1 \mathrm{~m}$ from marsh edge), (2) near marsh-edge SAV (SAV habitat $<1 \mathrm{~m}$ from marsh edge), and (3) non-vegetated bottom. We tested the null hypotheses that nekton density, biomass, and diversity were unrelated to habitat type or habitat characteristics. Ninety-six quantitative samples were taken with a $1 \mathrm{~m}^{2}$ throw trap between September 2001 and July 2002. Using multivariate analysis of variance (MANOVA), a significant habitat type by season interaction was found (Wilks' $\lambda=0.32, F_{24,259}=4.21, p<0.0001$ ) for nekton density, biomass, and diversity. Simple linear regression showed a positive relationship between SAV and nekton biomass ( $\mathrm{p}<0.0001$ ); however, distance of the vegetated habitat from the marsh edge did not significantly influence SAV or nekton biomass. SAV biomass, but not location, appears to be a dominant factor that influences nekton use within these small brackish marsh ponds. This study highlights some of the intricacies associated with the identification and use of broad scale habitat classification for management purposes. Although brackish marsh SAV habitat types support higher densities of nekton compared to non-vegetated habitat, variation within this gross classification indicates a wide range of habitat 'value' that needs to be considered for management purposes.
\end{abstract}

KEY WORDS: Brackish marsh · Nekton habitat · Ruppia maritima L. · Louisiana $\cdot$ Submerged aquatic vegetation $\cdot \mathrm{SAV} \cdot \mathrm{SAV}$ biomass $\cdot$ Habitat location

\section{INTRODUCTION}

Estuarine dependent nekton (fishes and decapod crustaceans) use a variety of habitat types to feed, spawn, and avoid predators. Nekton abundance and diversity have generally been shown to be higher along salt marsh edges (e.g. Baltz et al. 1993, Peterson \& Turner 1994), within seagrass beds (Connolly 1994), and within freshwater submerged aquatic vegetation (SAV) beds (Rozas \& Odum 1987a, Castellanos \& Rozas
2001) than within non-vegetated habitats. As such, shallow-water vegetated habitats are considered to be essential fish habitat $(\mathrm{EFH})$ as defined by the Magnuson-Stevens Fishery and Management Act (US Public Law 94-265) amended in 1996. However, few studies have addressed nekton use of SAV habitats in brackish marsh environments (but see Duffy \& Baltz 1998). Furthermore, most prior studies have used interhabitat comparisons to identify higher nekton abundance and diversity, but intrahabitat variability has not 
been thoroughly examined. In defining EFH, similar habitats are assumed to be equivalent regardless of location or other defining characteristics, such as habitat complexity, but this has not been thoroughly investigated.

In general, SAV habitat is assumed to be valuable because it provides both refuge from predators and a rich source of food for resident and estuarine dependent nekton (Rozas \& Odum 1988, Heck et al. 2003). The structural heterogeneity of SAV habitats provides camouflage and hiding places for juvenile nekton to take refuge from predators (e.g. Rozas \& Odum 1988, Woodley \& Peterson 2003). Vegetated habitats are also hypothesized to be high quality growth environments for juvenile nekton (Heck et al. 2003), because vegetated habitats support greater infaunal communities (benthic and epiphytic algae, detritus, and infaunal organisms) than do non-vegetated habitats (Edgar 1999).

The location and characteristics of SAV beds vary within a landscape, leading to the hypothesis that heterogeneity (i.e. habitat patch size, adjacent habitat type, distance from marsh edge) of SAV habitats may influence nekton use (Irlandi \& Crawford 1997, Eggleston et al. 1998). Within SAV habitats, nekton use may vary depending on the degree of refugia provided by a particular location within a bed (i.e. proximity to marsh edge; Raposa \& Oviatt 2000). Other studies have suggested that intrahabitat variability defined by vegetation species composition, morphology, biomass, or density of vegetation may also be important factors that influence nekton use of SAV beds (Dionne \& Folt 1991, Edgar \& Klumpp 2003).

This study was designed to examine intrahabitat variability of brackish marsh SAV habitat use by nekton. Specifically, we examined the effects of location (defined by distance from marsh edge) and complexity (defined by SAV biomass) on nekton community density, biomass, and diversity in monospecific brackish marsh SAV beds of widgeon grass Ruppia maritima L. The relative habitat value of $R$. maritima L. beds was also compared to that of adjacent non-vegetated bottom habitat.

\section{MATERIALS AND METHODS}

Study area. The study was conducted in ponds within Marsh Island State Wildlife Refuge (MIWR), Louisiana (Fig. 1). MIWR is located between the Gulf of Mexico and Vermilion, West Côte Blanche, and East Côte Blanche Bays. Coastal Louisiana contains over 5 million ponds and lakes, encompassing $7214 \mathrm{~km}^{2}$, with smaller ponds being more numerous and containing more SAV than larger ponds (Chabreck 1971). MIWR comprises 28300 ha of tidally influenced brackish marsh and ponds (Chabreck et al. 2001). Brackish marsh contains the greatest density of ponds of the 4 marsh types (fresh, intermediate, brackish, saline) in coastal Louisiana (Chabreck 1971). During our study, marsh ponds supported monospecific stands of Ruppia maritima L., but species composition at MIWR has varied among and within years (Nyman \& Chabreck 1996). The Louisiana Department of Wildlife and Fisheries (LDWF) manages portions of MIWR for increased SAV abundance in order to support wintering and migrating waterfowl, nesting shorebird habitat, and to slow marsh loss. The study was conducted within ponds in the unmanaged areas of MIWR so that managed areas with restricted nekton access could be avoided (e.g. Rogers et al. 1992).

Study ponds were selected to include a range of pond sizes and number of tidal channels that represent the natural variability of the system. Large and small tidal channels are common, and connect lakes to a complex system of ponds throughout MIWR. The study ponds ranged from 0.20 to $1.87 \mathrm{ha}$, and 1 to 5 tidal channels connected each pond to the larger system.

Sampling design. The study was conducted using a stratified random sampling design. Samples were collected from 8 randomly selected ponds (Fig. 1). In each of the 8 ponds, 3 habitat types were randomly sampled, (1) inner-pond SAV (Ruppia maritima L.) (IP: SAV > $1 \mathrm{~m}$ from emergent marsh edge), (2) near-marsh edge SAV (R. maritima L.) (NME: SAV $<1 \mathrm{~m}$ from emergent marsh edge), and (3) non-vegetated bottom (NB), leading to a total of 24 samples per collection period ( 8 ponds by 3 habitat types). Each of the 8 ponds was sampled 4 times (September 2001, December 2001, March 2002, July 2002), totaling 96 samples (24 samples per collection by 4 time periods).

All sampling occurred when the emergent marsh was not flooded and nekton was concentrated in marsh ponds. A $1 \mathrm{~m}^{2}$ aluminum-sided throw trap, similar to that described in Kushlan (1981), was used to quantitatively sample nekton. Sample sites were randomly selected within the 3 habitat types (IP, NME, NB). Sweeps with a $1 \mathrm{~m}$ wide bar seine ( $3 \mathrm{~mm}$ mesh size) were made to remove nekton from the trap. Five consecutive sweeps without collecting organisms were completed before the trap was considered to be free of nekton. Nekton were frozen and returned to the laboratory, where they were sorted and identified to species level or to lowest possible taxon. Total length $(\mathrm{TL}, \mathrm{mm})$ of fish and shrimp and carapace width (CW, $\mathrm{mm}$ ) of crabs were measured. All nekton were weighed to the nearest $0.001 \mathrm{~g}$ wet wt to determine biomass ( $g$ wet wt $\mathrm{m}^{-2}$ ). Density (ind. $\mathrm{m}^{-2}$ ) was calculated for each throw trap sample. Nekton community diversity for each sample was determined using the Shannon-Wiener diversity index ( $H^{\prime}$ ) (Magurran 1988). 

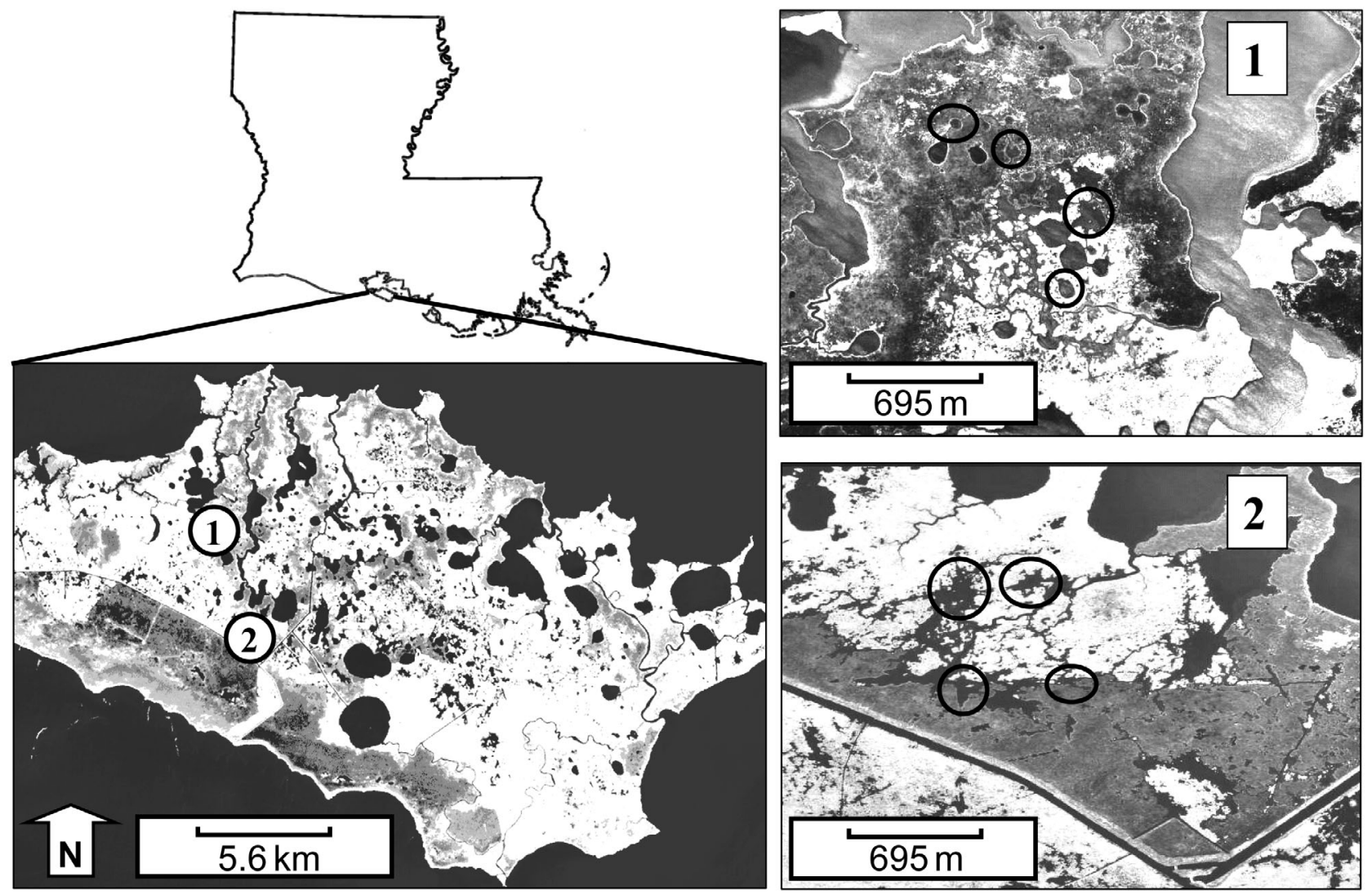

Fig. 1. Marsh Island State Wildlife Refuge (MIWR), Louisiana, located between Vermilion Bay, West Côte Blanche Bay, East Côte Blanche Bay, and the Gulf of Mexico. 1 \& 2 = study areas. Specific study ponds circled in enlarged maps of study areas

In throw trap samples containing $\mathrm{SAV}$, the vegetation was removed prior to nekton removal. Vegetation was removed from within the throw trap by hand and rake. The SAV was placed on ice and returned to the laboratory for processing. Vegetation was dried to a constant weight at $65^{\circ} \mathrm{C}$ and weighed to the nearest $0.001 \mathrm{~g}$ dry wt to determine dry weight ( $\mathrm{g}$ dry $\mathrm{wt} \mathrm{m}^{-2}$ ).

Mean water depth $(\mathrm{cm})$ calculated from 3 random measurements within the $1 \mathrm{~m}^{2}$ sample, distance to the nearest emergent marsh edge $(\mathrm{m})$, and Secchi disk depth $(\mathrm{cm})$ were measured at each throw trap. Water temperature $\left({ }^{\circ} \mathrm{C}\right)$, salinity (PSU), and dissolved oxygen $\left(\mathrm{mg} \mathrm{l}^{-1}\right)$ were measured with a YSI Model 556 water quality monitor at each sample location following throw trap deployment (i.e. within the throw trap but prior to SAV or nekton removal).

Statistical analyses. All statistical analyses were performed using SAS software (SAS Institute 1989) and an $\alpha$ level of 0.05 was used to determine significance. All data (SAV, nekton, and environmental) were tested for normality, by examining model residuals and homogeneity of variance to satisfy the assumptions of statistical analyses performed. Subsequent logarithmic $\left[\log _{10}(x+1)\right]$ transformation was necessary only for nekton biomass data.

Multivariate analysis of variance (MANOVA) was used to test the null hypotheses that nekton biomass, nekton density, nekton diversity, and SAV biomass were equal among ponds, seasons, habitats, and season by habitat interactions (SAS Institute 1989). Post MANOVA procedures, in the presence of significant interactions, included analysis of simple main effects and interpretation of standardized canonical coefficients.

Using distance as a covariate, analysis of covariance (ANCOVA) models were used to determine if nekton and SAV biomass differed among season, habitat, season by habitat interactions, and ponds. Type III SS were interpreted for results. Linear regression was used to examine the potential relationship between SAV biomass (independent predictor variable) and nekton biomass (dependent response variable).

Water depth, distance to marsh edge, Secchi disk depth, water temperature, salinity, and dissolved oxygen were analyzed with ANOVA to test for differences among season, habitat, season by habitat interactions, and pond. 


\section{RESULTS}

\section{Environmental variables}

Physicochemical variables measured were typical of Louisiana's brackish marsh systems (temperature: $24.5^{\circ} \mathrm{C} \pm 0.6 \mathrm{SE}$; dissolved oxygen: $5.0 \mathrm{mg} \mathrm{l}^{-1} \pm 0.3 \mathrm{SE}$; salinity: 4.1 PSU $\pm 0.2 \mathrm{SE}\left(\mathrm{PSU}=\mathrm{g} \mathrm{l}^{-1}\right.$ ); secchi: $19.4 \mathrm{~cm}$ $\pm 0.9 \mathrm{SE}$ ). Overall, vegetated habitats (IP and NME) were similar, and were significantly shallower and closer to the emergent marsh edge than NB ( $p<$ 0.0001) (Fig. 2).

\section{Nekton}

A total of 5041 individuals among 28 species were collected from 96 throw trap samples. Twenty-four species made up the majority of total catch abundance $(77.4 \%)$. Four decapod crustacean species were collected and composed $22.6 \%$ of total abundance (Table 1). Resident marsh species dominated the total catch. NME habitat contributed the most to total nek-

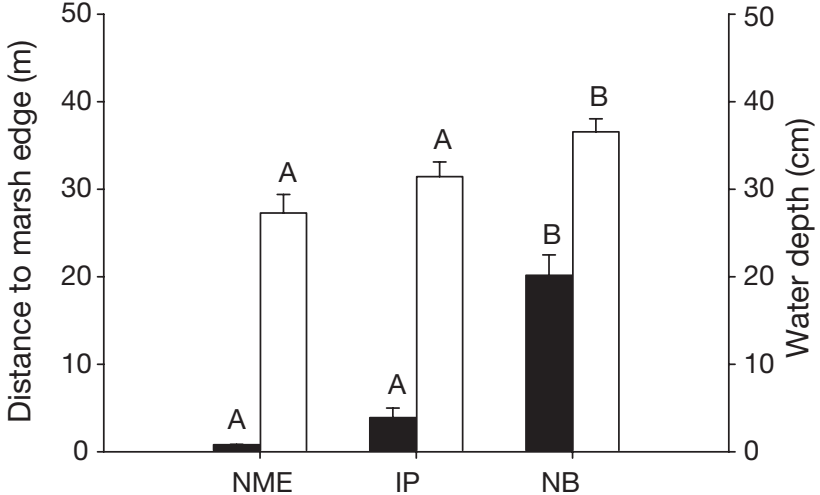

Fig. 2. Mean water depth (white bars) and distance to marsh edge (dark bars) by habitat type. NME = near marsh edge submerged aquatic vegetation (SAV), IP = inner-pond SAV, $\mathrm{NB}=$ non-vegetated bottom, $\mathrm{A}, \mathrm{B}=$ significant differences

$(\mathrm{p}<0.05)$, error bars $=\mathrm{SE}$ for individual means, $\mathrm{N}=96$

ton biomass, followed by IP, then NB (Table 2). Four numerically dominant taxa (rainwater killifish Lucania parva, sheepshead minnow Cyprinodon variegatus, grass shrimp Palaemonetes spp., sailfin molly Poecilia

Table 1. Total nekton abundance (no. individuals) and \% total catch by habitat and season. NME = near-marsh edge submerged aquatic vegetation (SAV), IP = inner-pond SAV, NB = non-vegetated bottom

\begin{tabular}{|c|c|c|c|c|c|c|c|c|c|}
\hline \multirow[t]{2}{*}{ Taxa } & \multirow{2}{*}{$\begin{array}{c}\text { Total } \\
\text { abundance }\end{array}$} & \multicolumn{3}{|c|}{ Abundance by habitat } & \multicolumn{4}{|c|}{ Abundance by season } & \multirow{2}{*}{$\begin{array}{l}\% \text { tota } \\
\text { catch }\end{array}$} \\
\hline & & NME & IP & NB & $\begin{array}{c}\text { Fall } \\
\text { (Sep 01) }\end{array}$ & $\begin{array}{l}\text { Winter } \\
\text { (Dec 01) }\end{array}$ & $\begin{array}{c}\text { Spring } \\
\text { (Mar 02) }\end{array}$ & $\begin{array}{l}\text { Summer } \\
\text { (Jul 02) }\end{array}$ & \\
\hline Lucania parva & 1510 & 712 & 797 & 1 & 210 & 78 & 5 & 1217 & 29.90 \\
\hline Cyprinodon variegatus & 994 & 558 & 432 & 4 & 188 & 16 & 3 & 787 & 19.71 \\
\hline Palaemonetes spp. & 861 & 407 & 431 & 23 & 149 & 129 & 77 & 506 & 17.07 \\
\hline Poecilia latipinna & 858 & 456 & 402 & 0 & 26 & 16 & 0 & 816 & 17.02 \\
\hline Litopenaeus setiferus & 238 & 88 & 137 & 13 & 217 & 17 & 1 & 3 & 4.72 \\
\hline Fundulus pulvereus & 217 & 126 & 91 & 0 & 7 & 6 & 0 & 204 & 4.30 \\
\hline Brevoortia patronus & 55 & 11 & 34 & 10 & 0 & 0 & 55 & 0 & 1.09 \\
\hline Callinectes sapidus & 39 & 20 & 13 & 6 & 10 & 16 & 5 & 8 & 0.77 \\
\hline Syngnathus louisianae & 36 & 15 & 21 & 0 & 0 & 2 & 0 & 34 & 0.71 \\
\hline Anchoa mitchilli & 35 & 2 & 13 & 20 & 12 & 9 & 6 & 8 & 0.69 \\
\hline Microgobius gulosus & 28 & 14 & 12 & 2 & 26 & 1 & 0 & 1 & 0.55 \\
\hline Micropogonias undulatus & 26 & 0 & 5 & 21 & 0 & 25 & 1 & 0 & 0.71 \\
\hline Syngnathus scovelli & 26 & 15 & 11 & 0 & 3 & 0 & 0 & 23 & 0.52 \\
\hline Gobiosoma bosc & 22 & 3 & 19 & 0 & 0 & 6 & 1 & 15 & 0.43 \\
\hline Myrophis punctatus & 22 & 14 & 6 & 2 & 13 & 1 & 1 & 7 & 0.43 \\
\hline Menidia beryllina & 20 & 4 & 16 & 0 & 17 & 2 & 1 & 0 & 0.39 \\
\hline Alosa chrysochloris & 16 & 0 & 0 & 16 & 0 & 16 & 0 & 0 & 0.31 \\
\hline Syngnathus floridae & 9 & 6 & 2 & 1 & 0 & 4 & 5 & 0 & 0.17 \\
\hline Fundulus grandis & 6 & 3 & 3 & 0 & 3 & 0 & 3 & 0 & 0.12 \\
\hline Mugil cephalus & 6 & 3 & 1 & 2 & 3 & 1 & 1 & 1 & 0.12 \\
\hline Farfantepenaeus aztecus & 3 & 2 & 0 & 1 & 1 & 2 & 0 & 0 & 0.05 \\
\hline Leiostomus xanthurus & 3 & 1 & 0 & 2 & 0 & 0 & 3 & 0 & 0.05 \\
\hline Mugil curema & 3 & 3 & 0 & 0 & 0 & 0 & 3 & 0 & 0.05 \\
\hline Clupeid & 2 & 0 & 2 & 0 & 0 & 2 & 0 & 0 & 0.03 \\
\hline Gambusia affinis & 2 & 2 & 0 & 0 & 0 & 0 & 0 & 2 & 0.04 \\
\hline Membras martinica & 2 & 0 & 1 & 1 & 0 & 1 & 0 & 1 & 0.03 \\
\hline Sciaenops ocellatus & 2 & 0 & 0 & 2 & 2 & 0 & 0 & 0 & 0.03 \\
\hline Total & 5041 & 2465 & 2449 & 127 & 887 & 350 & 171 & 3633 & 100 \\
\hline
\end{tabular}


Table 2. Total nekton biomass ( $\mathrm{g}$ wet $\mathrm{wt}^{-2}$ ) and \% total catch by habitat type and season

\begin{tabular}{|c|c|c|c|c|c|c|c|c|c|}
\hline \multirow[t]{2}{*}{ Taxa } & \multirow{2}{*}{$\begin{array}{c}\text { Total } \\
\text { biomass }\end{array}$} & \multicolumn{3}{|c|}{ Biomass by habitat } & \multicolumn{4}{|c|}{ Biomass by season } & \multirow{2}{*}{$\begin{array}{l}\% \text { total } \\
\text { catch }\end{array}$} \\
\hline & & NME & IP & NB & $\begin{array}{c}\text { Fall } \\
\text { (Sep 01) }\end{array}$ & $\begin{array}{l}\text { Winter } \\
\text { (Dec 01) }\end{array}$ & $\begin{array}{c}\text { Spring } \\
\text { (Mar 02) }\end{array}$ & $\begin{array}{l}\text { Summer } \\
\text { (Jul 02) }\end{array}$ & \\
\hline Callinectes sapidus & 341.4 & 328.3 & 12.4 & 0.8 & 98.6 & 76.9 & 1.2 & 164.8 & 25.67 \\
\hline Lucania parva & 237.8 & 101.6 & 136.2 & 0.0 & 32.4 & 18.0 & 2.3 & 185.2 & 17.88 \\
\hline Cyprinodon variegatus & 203.4 & 127.0 & 72.8 & 3.6 & 40.9 & 13.2 & 3.5 & 145.8 & 15.29 \\
\hline Palaemonetes spp. & 125.8 & 56.1 & 65.1 & 4.6 & 22.0 & 13.8 & 14.0 & 76.1 & 9.46 \\
\hline Poecilia latipinna & 96.0 & 54.2 & 41.8 & 0.0 & 7.2 & 5.6 & 0.0 & 83.3 & 7.22 \\
\hline Mugil cephalus & 92.7 & 30.8 & 34.6 & 27.2 & 30.8 & 34.6 & 20.9 & 6.3 & 6.97 \\
\hline Litopenaeus setiferus & 91.3 & 37.6 & 49.0 & 4.7 & 86.9 & 3.9 & 0.3 & 0.2 & 6.86 \\
\hline Fundulus pulvereus & 48.5 & 27.9 & 20.6 & 0.0 & 3.7 & 4.1 & 0.0 & 40.7 & 3.64 \\
\hline Fundulus grandis & 14.4 & 11.6 & 2.8 & 0.0 & 1.0 & 0.0 & 13.3 & 0.0 & 1.08 \\
\hline Myrophis punctatus & 13.1 & 7.9 & 2.6 & 2.6 & 8.4 & 1.5 & 1.0 & 2.2 & 0.98 \\
\hline Anchoa mitchilli & 10.7 & 0.7 & 3.7 & 6.3 & 3.8 & 2.2 & 1.1 & 3.6 & 0.80 \\
\hline Syngnathus scovelli & 9.9 & 4.9 & 5.0 & 0.0 & 0.4 & 0.0 & 0.0 & 9.5 & 0.74 \\
\hline Microgobius gulosus & 7.8 & 4.3 & 3.2 & 0.3 & 6.2 & 0.3 & 0.0 & 1.3 & 0.58 \\
\hline Syngnathus louisianae & 7.6 & 3.3 & 4.3 & 0.0 & 0.0 & 0.1 & 0.0 & 7.4 & 0.57 \\
\hline Micropogonias undulatus & 6.1 & 0.0 & 0.6 & 5.6 & 0.0 & 6.1 & 0.1 & 0.0 & 0.46 \\
\hline Gobiosoma bosc & 5.8 & 0.8 & 5.0 & 0.0 & 0.0 & 1.5 & 0.2 & 4.1 & 0.43 \\
\hline Menidia beryllina & 5.5 & 1.6 & 3.8 & 0.0 & 4.4 & 0.6 & 0.5 & 0.0 & 0.41 \\
\hline Brevoortia patronus & 3.7 & 0.6 & 2.4 & 0.7 & 0.0 & 0.0 & 3.7 & 0.0 & 0.28 \\
\hline Alosa chrysochloris & 2.6 & 0.0 & 0.0 & 2.6 & 0.0 & 2.6 & 0.0 & 0.0 & 0.19 \\
\hline Farfantepenaeus aztecus & 2.0 & 0.8 & 0.0 & 1.2 & 0.0 & 2.0 & 0.0 & 0.0 & 0.15 \\
\hline Syngnathus floridae & 1.7 & 0.9 & 0.7 & 0.1 & 0.0 & 0.9 & 0.8 & 0.0 & 0.13 \\
\hline Mugil curema & 0.7 & 0.7 & 0.0 & 0.0 & 0.0 & 0.0 & 0.7 & 0.0 & 0.05 \\
\hline Membras martinica & 0.7 & 0.0 & 0.4 & 0.3 & 0.0 & 0.3 & 0.0 & 0.4 & 0.06 \\
\hline Leiostomus xanthurus & 0.6 & 0.0 & 0.0 & 0.5 & 0.0 & 0.0 & 0.6 & 0.0 & 0.04 \\
\hline Gambusia affinis & 0.4 & 0.4 & 0.0 & 0.0 & 0.0 & 0.0 & 0.0 & 0.4 & 0.03 \\
\hline Clupeid & 0.1 & 0.0 & 0.1 & 0.0 & 0.0 & 0.1 & 0.0 & 0.0 & 0.01 \\
\hline Sciaenops ocellatus & 0.1 & 0.0 & 0.0 & 0.1 & 0.1 & 0.0 & 0.0 & 0.0 & 0.01 \\
\hline Total & 1330.1 & 802.1 & 466.9 & 61.1 & 346.6 & 188.3 & 64.1 & 731.2 & 100.00 \\
\hline
\end{tabular}

latipinna) composed $83.6 \%$ of total nekton abundance (Table 1), and $50 \%$ of the total nekton biomass (Table 2). All numerically dominant taxa were more abundant in SAV habitat types (NME and IP) than in NB habitat types (Table 1).

A significant multivariate effect was found for the habitat type by season interaction (Wilks' $\lambda=0.32$, $F_{24,259}=4.21, \mathrm{p}<0.0001$; Fig. 3). Further investigation of the standardized canonical coefficients showed that nekton density contributed most to the significant interaction of habitat type by season (nekton density = 0.98, SAV biomass $=0.64$, nekton biomass $=0.58$, diversity $=0.25$ ). Investigation of simple effects for nekton density and nekton biomass indicated a seasonal ( $p<0.01)$ and habitat $(p<0.0001)$ effect. Highest nekton densities occurred during summer and in SAV habitat types (IP and NME) (Fig. 3). Lowest nekton densities occurred in spring and in the NB habitat type (Fig. 3). Simple effects tests for nekton diversity indicated a seasonal $(\mathrm{p}<0.05)$ and habitat $(\mathrm{p}<0.05)$ effect.

A significant multivariate effect was found for the pond effect (Wilks' $\lambda=0.44, F_{28,268}=2.45, \mathrm{p}<0.0001$ ). Differences among ponds could not be accounted for by variation in pond size, distance from main channel, number of tidal channels, or the amount of emergent marsh edge.

\section{Submerged aquatic vegetation (SAV)}

Investigation of simple effects for SAV biomass showed significant differences by season, habitat types, and pond ( $p<0.05$; Fig. 3). July had significantly higher SAV biomass than other seasons, whereas March had the lowest SAV biomass. Similar to the nekton variables, differences in SAV biomass among ponds could not be explained by variation in pond size, distance from main channel, number of tidal channels, or amount of emergent marsh edge.

\section{Nekton biomass, SAV biomass, and distance from marsh edge}

Linear regression showed a significant positive relationship between nekton biomass and SAV biomass $\left(r^{2}=0.46 ; p<0.0001\right)$ (Fig. 4). ANCOVA indicated that 

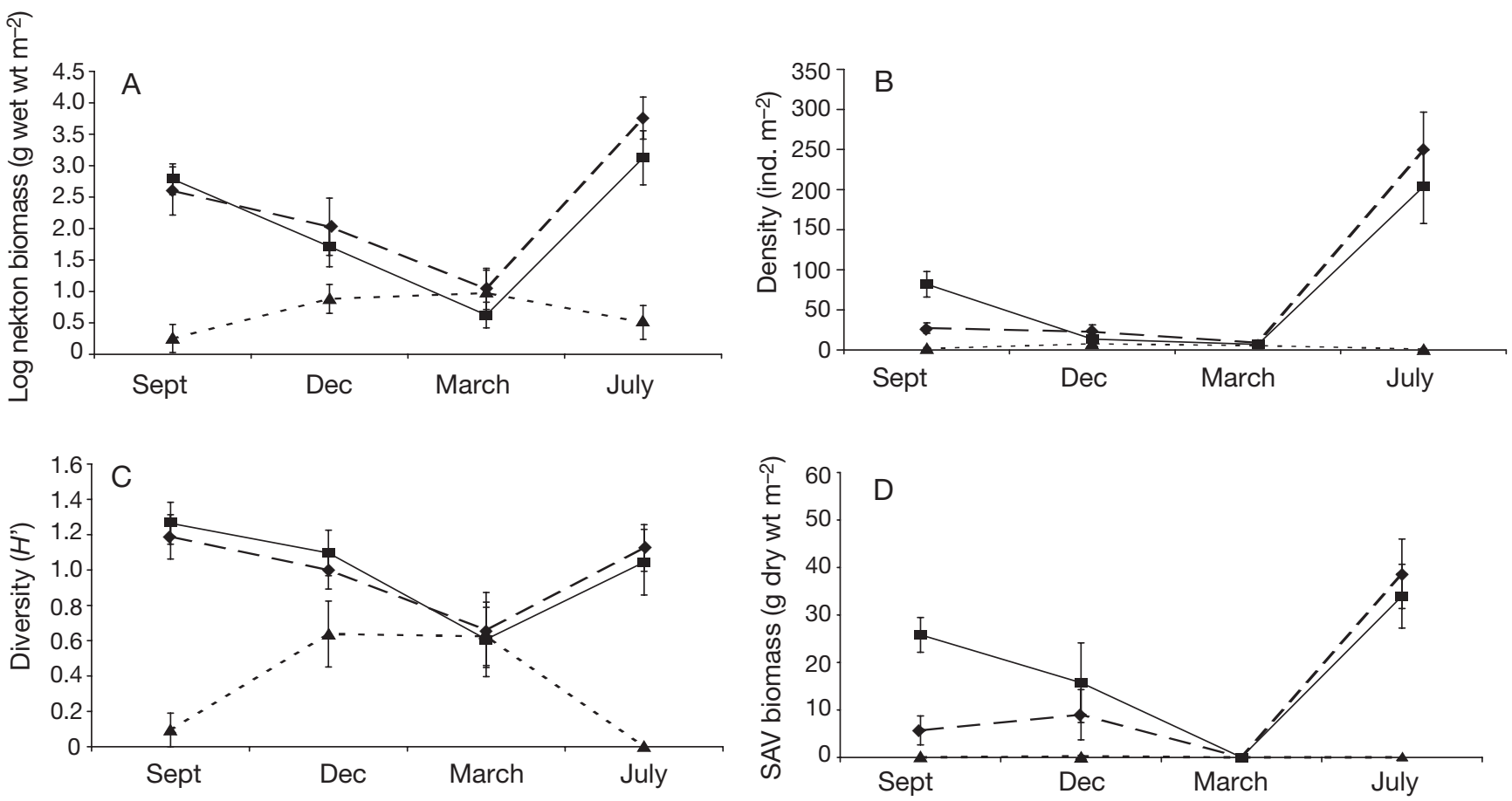

Fig. 3. (A) Mean nekton biomass (g wet wt $\left.\mathrm{m}^{-2}\right)\left(\log _{10}[x+1]\right.$ transformed), (B) mean nekton density (ind. $\left.\mathrm{m}^{-2}\right)$, (C) mean nekton diversity (Shannon-Wiener diversity index $H^{\prime}$ ), and (D) mean SAV biomass (g dry wt $\mathrm{m}^{-2}$ ). Sampling conducted in Fall (September 2001), Winter (December 2001), Spring (March 2002), and Summer (July 2002). $\bullet$ and long dashed line = NME habitat,

and solid line = IP habitat, $\boldsymbol{\Lambda}$ and short dashed line = NB habitat, error bars $=$ SE for individual means

nekton biomass and SAV biomass did not differ significantly with distance from the emergent marsh edge ( $p=0.09$ and $p=0.32$, respectively).

\section{DISCUSSION}

Past studies concluded that SAV habitats support greater nekton use than do non-vegetated habitats, in salt and freshwater environments (e.g. Connolly 1994, Castellanos \& Rozas 2001). Despite extensive work on nekton use of vegetated habitats, few studies have quantitatively examined nekton use of brackish submerged vegetation habitats (Minello 1999, but see Duffy \& Baltz 1998), and we are aware of no studies other than ours that have examined the effects of multiple indicators of intrahabitat variability of monospecific brackish SAV habitats (Ruppia maritima L.) on nekton use. This study documented significantly higher nekton use of SAV versus non-vegetated brackish habitats. Furthermore, within the SAV habitat types sampled, intrahabitat variability defined by SAV biomass was highly related to nekton use; in contrast, intrahabitat variability defined by distance from marsh edge, pond size, distance from main channel, number of tidal channels, or amount of emergent marsh edge did not significantly influence nekton use.

\section{SAV biomass}

Vegetative structural complexity is often listed as a potential variable accounting for intrahabitat differences in nekton use, density, abundance, or survival in SAV beds. Vegetative structural complexity has been defined in several ways including plant morphology (e.g. leaf complexity), shoot density, and biomass.

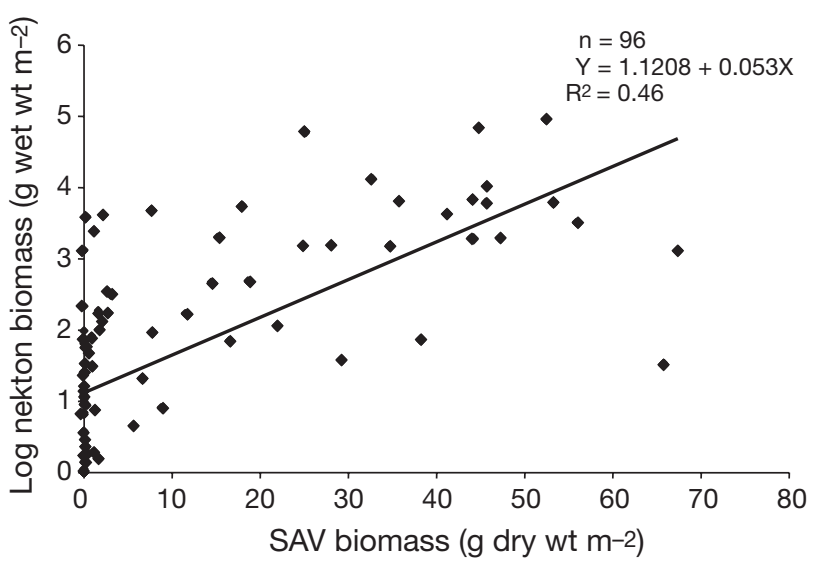

Fig. 4. $\log _{10}(x+1)$ transformed nekton biomass (g wet wt $\left.\mathrm{m}^{-2}\right)$ against SAV biomass (g dry wt $\mathrm{m}^{-2}$ ) 
Within monospecific stands of SAV, biomass can be used as a proxy for vegetative structural complexity based on the assumption that increased SAV biomass represents increased \% cover and structure, and therefore may (1) provide increased refuge, and (2) provide increased food by enhancing areas for epiphytes and other prey items to attach. In the Ruppia maritima L. habitats we sampled, SAV biomass and nekton biomass were strongly and positively correlated. Prior studies in saline environments also found a significant relationship between plant biomass and faunal abundance (Raposa \& Oviatt 2000).

An early study by Heck \& Orth (1980) suggested that the greatest abundance of nekton would be found in areas with 'moderate' levels of vegetation (in terms of $\%$ cover or biomass). They argued that minimal vegetation offers poor refuge, whereas dense vegetation contributes to poor water quality conditions (e.g. dissolved oxygen) and reduces foraging ability. Similarly, Raposa \& Oviatt (2000) suggested that their findings for fourspine stickleback Apeltes quadracus, seaboard goby Gobiosoma ginsburgi, and macroalgal biomass Chaetomorpha spp. support this hypothesis, as highest abundances were associated with the most intermediate levels of macroalgal biomass. At the other end of the spectrum, Castellanos \& Rozas (2001) suggested that their lack of correlation between SAV biomass and nekton density may be due to low nekton abundance in the dense Scirpus americanus streamside marsh they sampled. In our March 2002 samples, minimal SAV biomass in all habitat types was reflected by a corresponding low nekton biomass. Because our catch was dominated by resident nekton, this low nekton abundance could not be attributed to seasonal fluctuations of transients within the study area. Low nekton abundance was likely associated with the minimal SAV biomass, which failed to offer much desirable habitat. In the present study, a plot of nekton biomass and SAV biomass (Ruppia maritima L.) failed to demonstrate this 'moderate level' trend noted by Heck \& Orth (1980), which could either be due to the absence of this pattern from $R$. maritima L. beds, or failure to sample 'high' $R$. maritima L. biomass during the study.

\section{Habitat location}

Although vegetative structural complexity may be an important variable, geographic location, which entails a greater landscape view of habitat and implies linkages among abiotic and biotic variables, it has recently become more frequently cited to explain both intrahabitat variation in nekton abundance, and also to better define the total environment in which organisms thrive (Irlandi \& Crawford 1997). In many studies, loca- tion is usually defined by adjacent habitats or distance from certain habitats, and has been shown to affect nekton abundance in freshwater marshes (Rozas \& Odum 1987b) and in seagrass beds (Raposa \& Oviatt 2000, Poulakis et al. 2003). In many cases, species that typically use marsh surfaces were found to be more abundant in habitats adjacent to the marsh surface. For example, Poulakis et al. (2003) found that proximity of seagrasses to fringing mangroves partly explained differences in nekton communities in Charlotte Harbor, Florida, with species typically found in mangroves also found in adjacent seagrass beds. Similarly, Hovel (2003) found that SAV location and landscape structure were the overriding factors influencing crab survival: SAV patch size produced both positive and negative effects on crab survival depending on geographic location.

In our study, location was defined as distance from the marsh edge, and was not found to be a significant factor explaining differences in nekton density, biomass, or diversity. This finding, which contradicts a number of studies that demonstrated that the marsh edge supports a high abundance of nekton (e.g. Baltz et al. 1993, Peterson \& Turner 1994), may largely be due to the scale at which our study was completed. Vegetated habitat types were located in close proximity to one another because marsh ponds were small $(<1.87 \mathrm{ha})$ and SAV beds fringed the marsh edge, rarely extending more than $5 \mathrm{~m}$ from the marsh edge. These results are similar to those of Raposa \& Oviatt (2000), who observed resident nekton species abundance in SAV beds to be similar within $10 \mathrm{~m}$ of the emergent marsh edge, but not at distances of 150 and $300 \mathrm{~m}$ from the marsh edge. They reported that most species found within $10 \mathrm{~m}$ of the marsh edge were species often abundant on the marsh surface. It is advantageous for resident marsh species to remain close to the emergent marsh edge at low tide, to facilitate quick movement onto the marsh surface when it becomes flooded. In addition, nearshore SAV provides increased refuge from deep-water predators (Ruiz et al. 1993). Studies that compared nekton abundance between flooded marsh and SAV habitats generally found the density of most species to be similar between the two habitats (Castellanos \& Rozas 2001).

\section{Nekton densities}

While few studies have quantified nekton densities in brackish marsh environments, and specifically in monospecific Ruppia maritima L. habitat types, several studies have provided density estimates for salt and freshwater environments for comparison. In our study, mean fish density in the brackish SAV habitats was 
$57.9 \pm 11.7$ (SE) ind. $\mathrm{m}^{-2}$ and crustacean density was $17.1 \pm 3.0$ (SE) ind. $\mathrm{m}^{-2}$. In salt water environments, studies in Florida, Texas, Louisiana, and Maine have measured densities ranging from 10 to 102 ind. $\mathrm{m}^{-2}$ (i.e. Sogard et al. 1987, Sogard 1989, Minello 1999, Lazzari 2002, Glancy et al. 2003). In freshwater environments, reported fish densities range from 19 to 31 ind. $\mathrm{m}^{-2}$ and crustacean densities from 4 to 271 ind. $\mathrm{m}^{-2}$ (Rozas \& Odum 1987a, 1988, Castellanos \& Rozas 2001). Duffy \& Baltz (1998) reported mean fish density of $12.5 \pm$ 1.6 (SE) ind. $\mathrm{m}^{-2}$ from brackish vegetated habitats in Lake Pontchartrain, Louisiana. Another study in Louisiana brackish marsh ponds, conducted during a similar time period to our study, reported lower nekton density (1.3 nekton $\left.\mathrm{m}^{-2}\right)$ and biomass $\left(0.4 \mathrm{~g} \mathrm{~m}^{-2}\right)$ than observed by us; however, SAV biomass was generally low, averaging less than $4 \mathrm{~g} \mathrm{~m}^{-2}$ throughout the study (Bush Thom et al. 2004).

Nekton densities in this study were generally similar to those reported in fresh, salt, and other brackish marsh environments; however, a wide range of nekton densities is noted. Variability in nekton densities between this study and others may be partially explained by habitat complexity, such as differences in SAV biomass as defined in this study, as well as by differences in SAV species and sampling protocol (i.e. sampling at different tidal stages). Tidal stage can influence nekton habitat use by providing access to some habitats at high tide and different habitats at low tide, thereby contributing to the broad range of nekton densities in intrahabitat comparisons. We sampled when the emergent marsh was not flooded and nekton restricted to the marsh ponds, SAV and non-vegetated habitats. Some studies that provide nekton densities for comparison do not specify whether sampling was conducted at high or low tide. Other studies sampled at high tide when the emergent marsh was flooded and nekton had access to the marsh, potentially decreasing nekton densities (i.e. Minello 1999, Castellanos \& Rozas 2001), or at low tide when nekton did not have access to the marsh surface (Rozas \& Odum 1987a, Lazzari 2002, Glancy et al. 2003). However, one study by Sogard et al. (1987) sampled at both high and low tides, and found that few species showed differences in density between high and low tide. Sampling at variable tidal stages may partially explain the wide range of nekton densities reported from intrahabitat comparisons; however, as data in this study suggest, habitat complexity (i.e. SAV biomass) is also likely an important factor.

\section{Management implications}

Although SAV habitats in all salinity zones are likely EFH for certain fishery species, differences in nekton densities across salinity zones indicate that not all SAV habitats may be equally essential for all species (sensu Peterson 2003). Furthermore, intrahabitat variabilityin this case, habitat complexity defined by SAV biomass within monospecific Ruppia maritima L. bedsmay affect the value of the SAV habitat. This study highlights some of the intricacies associated with macro-scale identification and the use of broad scale habitat types for management purposes. While brackish marsh SAV certainly supports high densities of nekton, variation within this gross classification indicates a wide range of habitat 'value' that needs to be considered. Additional analyses that examine the functional relationship between specific microhabitat characteristics and nekton use are required.

Acknowledgements. We thank C. Bush Thom, M. Caudill, T. Mercantal, B. Milan, B. Piazza, J. Plunket, A. Podey, S. Schales, C. Vickery, and C. Winslow for assistance with collection and field logistics. Drs. L. Rozas and A. Rutherford provided helpful comments throughout the project. The Louisiana Department of Wildlife and Fisheries provided field lodging and logistical support. Financial support for this study was provided by contracts from the National Marine Fisheries Service to M.K.L., from Marsh Island Wildlife Refuge to M.K.L. and J.A.N. (contract no. CFMS 579120), and from the United States Geological Survey.

\section{LITERATURE CITED}

Baltz DM, Rakocinski C, Fleeger JW (1993) Microhabitat use by marsh-edge fishes in a Louisiana estuary. Environ Biol Fish 36:109-126

Bush Thom CS, La Peyre MK, Nyman JA (2004) Evaluation of nekton use and habitat characteristics of restored Louisiana marsh. Ecol Eng 23:63-75

Castellanos DL, Rozas LP (2001) Nekton use of submerged aquatic vegetation, marsh, and shallow unvegetated bottom in the Atchafalaya River Delta, a Louisiana tidal freshwater ecosystem. Estuaries 24:184-197

Chabreck RH (1971) Ponds and lakes of the Louisiana coastal marshes and their value to fish and wildlife. Proc Annu Conf Game Fish Comm 25:206-215

Chabreck RH, Linscombe G, Hartley S, Johnston JB, Martucci A (2001) Coastal Louisiana (interactive multimedia): marsh-vegetation types. USGS-National Wetlands Research Center, Lafayette, LA

Connolly RM (1994) A comparison of fish assemblages from seagrass and unvegetated areas of a southern Australian estuary. Aust J Mar Freshw Res 45:1033-1044

Dionne M, Folt CL (1991) An experimental analysis of macrophyte growth forms as fish foraging habitat. Can J Fish Aquat Sci 48:123-131

Duffy KC, Baltz DM (1998) Comparison of fish assemblages associated with native and exotic submerged macrophytes in the Lake Pontchartrain estuary, USA. J Exp Mar Biol Ecol 223:199-221

Edgar GJ (1999) Experimental analysis of structural versus trophic importance of seagrass beds. I. Effects on macrofaunal and meiofaunal invertebrates. Vie Milieu 49: 239-248

Edgar GJ, Klumpp DW (2003) Consistencies over regional scales in assemblages of mobile epifauna associated with 
natural and artificial plants of different shape. Aquat Bot 75:275-291

Eggleston DB, Etherington LL, Elis WE (1998) Organism response to habitat patchiness: species and habitatdependent recruitment of decapod crustaceans. J Exp Mar Biol Ecol 223:111-132

Glancy TP, Frazer TK, Cichra CE, Lindberg WJ (2003) Comparative patterns of occupancy by decapod crustaceans in seagrass, oyster, and marsh-edge habitats in a northeast Gulf of Mexico estuary. Estuaries 26:1291-1301

Heck KL, Orth RJ (1980) Structural components of eelgrass (Zostera marina) meadows in the lower Chesapeake Bay-decapod crustacean. Estuaries 3:289-295

Heck KL, Hays G, Orth RJ (2003) Critical evaluation of the nursery role hypothesis for seagrass meadows. Mar Ecol Prog Ser 253:123-136

Hovel KA (2003) Habitat fragmentation in marine landscapes: relative effects of habitat cover and configuration on juvenile crab survival in California and North Carolina seagrass beds. Biol Conserv 110:401-412

Irlandi EA, Crawford MK (1997) Habitat linkages: the effect of intertidal saltmarshes and adjacent subtidal habitats on abundance, movement, and growth of an estuarine fish. Oecologia 110:222-230

Kushlan JA (1981) Sampling characteristics of enclosure fish traps. Trans Am Fish Soc 110:557-562

Lazzari M (2002) Epibenthic fishes and decapod crustaceans in northern estuaries: a comparison of vegetated and unvegetated habitats in Maine. Estuaries 25:1210-1218

Magurran AE (1988) Ecological diversity and its measurements. Princeton University Press, Princeton, NJ

Minello TJ (1999) Nekton densities in shallow estuarine habitats of Texas and Louisiana and the identification of essential fish habitat. Am Fish Soc Symp 22:43-75

Nyman JA, Chabreck RH (1996) Some effects of 30 years of weir management on coastal marsh aquatic vegetation and implications to waterfowl management. Gulf Mex Sci $1: 16-25$

Peterson MS (2003) A conceptual view of environment-habitat-production linkages in tidal river estuaries. Rev Fish Sci 11:291-313

Editorial responsibility: Kenneth Heck Jr (Contributing Editor), Dauphin Island, Alabama, USA
Peterson GW, Turner RE (1994) The value of salt marsh edge vs. interior as a habitat for fish and decapod crustaceans in a Louisiana tidal marsh. Estuaries 17:235-262

Poulakis GR, Blewett DA, Mitchell ME (2003) The effects of season and proximity to fringing mangroves on seagrassassociated fish communities in Charlotte Harbor, Florida. Gulf Mex Sci 2:171-184

Raposa KB, Oviatt CA (2000) The influence of contiguous shoreline type, distance from shore, and vegetation biomass on nekton community structure in eelgrass beds. Estuaries 23:46-55

Rogers DR, Rogers BD, Herke WH (1992) Effects of a marsh management plan on fishery communities in coastal Louisiana. Wetlands 12:53-62

Rozas LP, Odum WE (1987a) Fish and macrocrustacean use of submerged plant beds in tidal freshwater marsh creeks. Mar Ecol Prog Ser 38:101-108

Rozas LP, Odum WE (1987b) The role of submerged aquatic vegetation in influencing the abundance of nekton on contiguous tidal fresh-water marshes. J Exp Mar Biol Ecol 114:289-300

Rozas LP, Odum WE (1988) Occupation of submerged aquatic vegetation by fishes: testing the roles of food and refuge. Oecologia 77:101-106

Ruiz GM, Hines AH, Posey MH (1993) Shallow water as a refuge habitat for fish and crustaceans in non-vegetated estuaries: an example from Chesapeake Bay. Mar Ecol Prog Ser 99:1-16

SAS Institute (1989) SAS/STAT User's Guide, Version 6, 4th edn, Vol 1. SAS Institute, Cary, NC

Sogard SM (1989) Colonization of artificial seagrass by fishes and decapod crustaceans-importance of proximity to natural eelgrass. J Exp Mar Biol Ecol 133:15-37

Sogard SM, Powell GN, Holmquist JG (1987) Epibenthic fish communities on Florida Bay banks: relations with physical parameters and seagrass cover. Mar Ecol Prog Ser 40: 25-39

Woodley CM, Peterson MS (2003) Measuring responses to simulated predation threat using behavioral and physiological metrics: the role of aquatic vegetation. Oecologia 136:155-160

Submitted: January 5, 2005; Accepted: April 19, 2006

Proofs received from author(s): November 1, 2006 